\title{
SOFC power plant with circulating fluidized bed gasifier
}

\author{
Yulia V. Volkova ${ }^{1,2,{ }^{*}}$, Vladimir A. Munts ${ }^{1}$, Dmitry B. Choynzonov ${ }^{1}$, and Nikita S. Plotnikov ${ }^{2}$ \\ ${ }^{1}$ Ural Federal University named after the first President of Russia B.N. Yeltsin, Ekaterinburg, Russia \\ ${ }^{2}$ Ural Industrial Company, LLC, Ekaterinburg, Russia
}

\begin{abstract}
Coal is used all over the world to meet the energy needs of industry and housing and communal services. The main requirements of coal using are environmental safety and efficiency. Increasing these parameters can be realized with the combination of a gasifier and fuel cells. The paper includes a variant of the thermal scheme of the power plant, which uses coal as a fuel, with its further gasification and conversion into electrical energy in a solid oxide fuel cell (SOFC) stacks. The developed scheme differs from traditional circuits by using a gasifier with an inhibited circulating fluidized bed (ICFB). In addition, the anode-off gases are used in the combustion chamber of the gasifier to maintain endothermic gasification reactions. This technologies combination allows increasing the energy system efficiency. The paper also includes the results of tests of an ICFB gasifier and analyze the available electrical power of the SOFC stacks. Analysis dependence EMF from the produced generator gas composition showed no significant effect on the available power of the electrochemical generator. Developed scheme allow excluding from the process the gas cleaning from tar after gasifier, which allowed to increase the efficiency and reduce the metal capacity of the developed equipment.
\end{abstract}

\section{Introduction}

Fossil fuels are used all over the world to meet the energy needs of industry and housing and communal services. The traditional method of using fuel is to burn and receive from that process heat and electricity. With the growth of the economy of developed countries, their consumption will only increase, which, in conditions of limited resources, can cause confrontation. Combustion of fossil fuels leads to an increase in emissions of pollutants into the atmosphere, which adversely affects the environmental situation around the world [1]. Therefore, many countries at the level of state programs have been developing energy-safe energy technologies, one of which is the fuel cell technology (FC) [2-8]. FC are electrochemical devices designed to directly convert the chemical energy of fuel into electrical energy [1].

\footnotetext{
${ }^{*}$ Corresponding author: sofcbase@gmail.com
} 


\subsection{Features of fuel cells and coal gasification technologies}

Low-temperature fuel cell predominantly works on hydrogen, and for their effective operation, it is necessary to use platinum as a catalyst. In the high-temperature fuel cells can be used as fuel the mixture of hydrogen and carbon monoxide and as the oxidizer can be dustfree air. Therefore, the high-temperature solid oxide fuel cells are most promising. Solid oxide fuel cells (SOFC) are high-temperature cells that operate at a temperature of 700$900^{\circ} \mathrm{C}$. For SOFC as electrolyte can be used a ceramic material based on zirconia stabilized by yttrium (YSZ, for example, $\mathrm{ZrO}_{2}+8 \mathrm{~mol} . \% \mathrm{Y}_{2} \mathrm{O}_{3}$ ) [21]. Advantages of SOFC allow using them in cogeneration cycles, which will have been significantly increasing the efficiency and environmental safety of the latter. Researchers of leading universities and companies carry out scientific work in the field of creating effective thermal circuits and cycles based on SOFC technology [10,11]. Since 2000, Wärtsilä has been developing 20-50kW power systems based on planar design SOFC. In 2009, the company developed a prototype power plant that uses $40 \% \mathrm{CH}_{4}, 34 \% \mathrm{~N}_{2}, 26 \% \mathrm{CO}$ biogas as fuel, seasonal changes in gas composition amount to $\pm 15 \%$. The electrical efficiency of such a system is at the level of $43 \%$, and the overall efficiency of $73-76 \%$ [11].

As a raw feedstock in thermal schemes with high-temperature fuel cells, coal is often considered, since it is the most common type of fossil fuel. Its reserves exceed the reserves of oil and natural gas. But when burning coal, a number of problems arise, such as ash residue, which must be removed and disposed of, the formation of sulfur and nitrogen oxides, as well as other harmful compounds; therefore, a significant number of technological processes and schemes are created to effectively convert coal to gas or heat. Since the last century, the humankind has developed schemes which use as a fuel the coal and it can produce combustible gas by gasification [19]. Coal gasification technology is the most promising and environmentally friendly technology in comparison with coal combustion way $[12,19]$. The most studied processes of high-temperature gasification of coal are gasification with a mixture of $\mathrm{H}_{2} \mathrm{O}$ and $\mathrm{O}_{2}$, carbon dioxide, a mixture of air and steam, hydrogen and air gasification. Recently, with the development of science and technology, new methods of gas gasification are being developed, one of which was described by S. Chen et al. In the publication [14]. This is the technology of supercritical gasification of coal, biomass, and organic waste. The essence of which is that when supercritical parameters are reached, water begins to have sufficient density to provide a significant dissolving capacity and diffusion higher than liquids, but with lower viscosity, which increases mass transfer. As a result, a homogeneous and fast reaction medium for gasification can be created $[15,16]$. Despite significant potential efficiency, this technology has a number of technological drawbacks in the implementation, such as the complexity of the equipment to achieve and maintain the supercritical parameter, the need for equipment certification, requires a large amount of water.

Producer gas, which generating during gasification, can be burned in boilers or combustion chambers of gas turbines to produce heat and electricity and can be converted to synthesis gas, which is a raw material for obtaining motor fuels, various fertilizers, synthetic natural gas, hydrogen, methanol, etc. To achieve more efficient use of fuel, gasification products can be used in SOFC. A team of authors led by A. T. Thattai et al. [15] carried out a thermodynamic study on the modernization of existing stations in the Netherlands, taking into account the inclusion of a generator in the SOFC in the circuit. Modernization of power plants up to $40 \mathrm{MW}$ in cycles of combined-cycle plants with coal gasification and SOFC stacks is possible without large modifications of plants. The authors showed that by using modern fuel cells and introducing a partial return of $\mathrm{CO}_{2}$ from the flue gases to the cycle, it is possible to increase the efficiency of the system by $9 \%$ and to reduce carbon dioxide emissions by $45 \%$. 
In the paper [18], two new cogeneration systems based on SOFC were compared. As a fuel, either synthesis gas from the gasifier or biogas from the anaerobic digestion reactor is used. M Yari et al. had determined that in the case of obtaining only electric energy, the scheme with the anaerobic digestion reactor and SOFC is more effective $(40.14 \%)$ than the gasifier circuit $(20.31 \%)$. But with the joint generation of electrical and thermal energy, the efficiency of the last scheme will be $58.75 \%$, and in the scheme using the gasification gas, the efficiency will be $51.05 \%$. On the other hand, the authors determined that using biogas from anaerobic gas technology is more cost-effective than using gas from the gasifier. When carrying out these calculations, the authors took into account the need to purify the generator gas from the gasifier from the tar, which unambiguously has a significant effect on the efficiency of the entire process. Tar is dangerous in that it can disable SOFC stacks [22, 23].

Consequently, the relevance of the use of synthesis gas and biogas in cogeneration cycles with SOFCs and their high efficiency is confirmed. The above technologies are very necessary nowadays because traditional methods of fuel use are associated with large losses of its potential. Combining the gasification process and SOFC technology allows significantly reduce the loss of chemical energy of the fuel, due to direct conversion to electricity.

\subsection{Advantages of combining coal gasification and solid oxide fuel cells technologies}

The main prerequisites for combining coal gasification and solid oxide fuel cells technologies:

- To produce the generating gas, it is necessary to supply heat to the gasification chamber, for support endothermic reactions. On the other hand, gases leaving the anode channel have a temperature at the level $800^{\circ} \mathrm{C}$, and these gases can be used as the heat source.

- Both for the cathode channel of the fuel cells and for the gasification chamber, the supply of dust-free air is needed.

- In planar design solid oxide fuel cells with an anode support, the latter is made of nickel cermet, which allows flowing in the anode channel of the reaction of water gas (shift) $\mathrm{CO}+\mathrm{H}_{2} \mathrm{H}=\mathrm{CO}_{2}+\mathrm{H}_{2}$ and it increases the amount of hydrogen participating in the reaction and the electric current will have been increasing.

- In solid oxide fuel cells, it is possible to use not only pure hydrogen, but also a mixture of $\mathrm{CO}$ and $\mathrm{H}_{2}$.

- When gas has been burning in turbines or boiler combustion chambers in the combustion chambers, nitrogen, which in the produced gas is $61.7 \%$ by volume, can create NOx formed in chemical reactions during combustion. In SOFC, due to the fact that the temperature is at $750-850^{\circ} \mathrm{C}$ (this is not enough for NOx formation, it is necessary from $1100^{\circ} \mathrm{C}$ ), it allows the power plant based on SOFC with coal gasification to be safe for the environment in comparison with traditional installations of this type

\section{Methods}

\subsection{The thermal circuit of the SOFC power plant with circulating fluidized bed gasifier}

To create the most effective heat scheme based on two technologies, special attention should be paid to choosing a gasifier. In most cases, the produced generator gas contains tar, which requires the additional cleaning unit. Therefore, for the new power plant, it was decided to 
use the coal gasification technology, which was developed and described Dubinin et al. in detail in [12]. The diagram of this gasifier is shown in Fig. 1.

The operation of this gasifier is as follows. Inert spherical particles had placed in a retort. In the internal retort 18 the coal dust had been burning to supply the necessary amount of heat for gasification processes. In the annular gap between the retorts 18 and 19 the process of air gasification of coal had been passing. Standpipes 8 and 15 are provided for circulating the electrocorundum. To allow the endothermic reaction to proceed in the gasification chamber 11, the heated electrocorundum which was heated in the chamber 16 had been supplied to the fluidized bed 21 through the riser 15 . Elecrocorundum was returned to the fluidized bed 5 in the combustion chamber for reheating using riser 8 after cooling. Steady circulation of particles between the chambers was carried out due to the difference in the hydraulic resistance of the circulating layer blocked by the spherical particles and the elecrocorundum column in the risers 8 and 15. The coal dust was fed into the combustion chamber by the nipple 25 and the air by the nipple 1 . The combustion products were removed at the outlet 14. Coal in the gasification chamber entered the fitting 7, the air on the fitting 22.

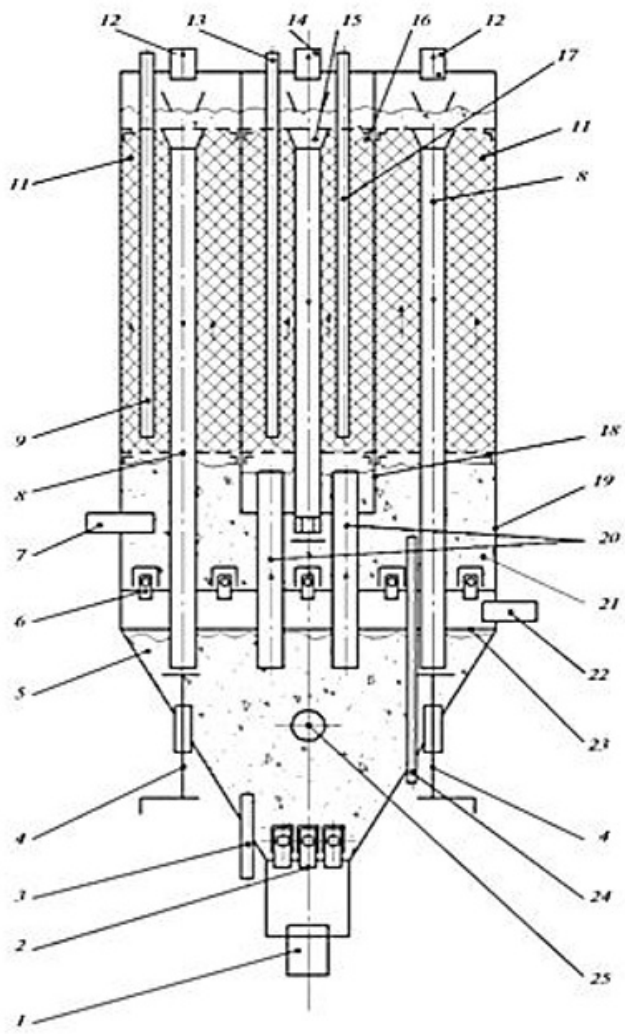

1 - air inlet for combustion; 2, 6 - air distribution grate the cap; 3 - fitting for removal of ash and slag; 4 - device (gate) for regulating the consumption of electrocorundum by lowering risers; 5 , 21 - pseudo-fluidized bed; 7 - fitting for feeding the coal in the gasification chamber; 8 - standpipe; 9 - a tube for measuring the temperature along the height of the gasification chamber; 11 spherical particles in the gasification chamber; 12 - gasification products exit; 13 - A tube for measuring the temperature along the height of the combustion chamber; 14 - combustion products outlet; 15 - riser standpipe into the combustion chamber; 16 - spherical particles in combustion chamber; 17 - device for taking samples of gasification products; 18 - internal retort; 19 - outer retort; 20 - lifting risers; 22 - air inlet for gasification; 23 - partition; 24 - ash outlet; 25 - coal dust feeding into the combustion chamber

Fig 1. Experimental bench for air gasification of coals in the inhibited circulating fluidized bed

During the experiments, it was found that with the consumption of coal and air in the combustion chamber $4.4 \mathrm{~kg} / \mathrm{h}$ and $22 \mathrm{~m}^{3} / \mathrm{h}$, and with the consumption of coal and air in the gasification chamber of $24 \mathrm{~kg} / \mathrm{h}$ and $34.9 \mathrm{~m}^{3} / \mathrm{h}$ in the gasification products there were no tar, and particles of the fraction 150-200 $\mu \mathrm{m}$ carried away from the combustion chamber had a dry ashless mass of $\sim 10 \%$, in the fraction $40-80 \mu \mathrm{m} \sim 15 \%$.

The gases which leaving the anode channel contain a small number of combustible components such as $\mathrm{CO}$ and $\mathrm{H}_{2}$, in addition, they have a temperature of $750-800{ }^{\circ} \mathrm{C}$. 
Therefore, they can be catalytically burned to support endothermic reactions in the production of the generator gas. Since the gasifier with inhibited circulation bed has a combustion chamber, it was decided to direct the gases leaving the SOFC into the internal retort 18 , where coal dust was previously burned, which will be filled with an aluminumbased catalyst.

Based on the experience of using SOFC stacks with anode-supported cells and a gasifier with IFCB, a scheme of a power plant using coal as a fuel was developed. The scheme of this power unit is shown in Fig. 2

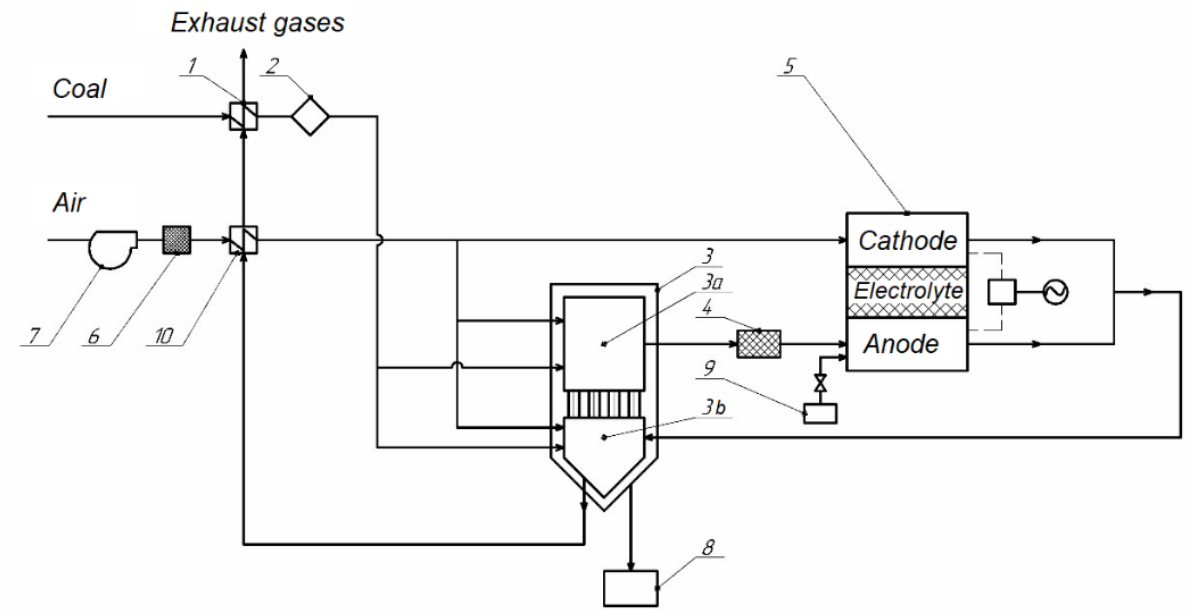

Fig 2. Scheme of the coal-fired power plant with a gasifier with a inhibited fluidized bed and solid oxide fuel cell stacks: 1-device for drying incoming coal, 2 coal crusher, 3 gasifier, 4- mechanical filter, 5- SOFC stacks, 6- air mechanical filter, 7-blower, 8-ash collector, 9-cylinder with a SOFC protective mixture (95\% $\mathrm{Ar} / 5 \% \mathrm{H} 2), 10$ - heat exchanger for heating air entering the cathode channel.

In the proposed scheme, the coal enters the drying chamber 1 to remove moisture and then feeding the grinding mill 2 for grinding into a fraction suitable for gasification. The generated generator gas passes through the mechanical filter 4 and enters the anode channel of the fuel cell 5. The air pre-cleaned of the dust in the mechanical filter 6 is supplied by the blower 7 for the heating in the heat exchanger 10, after which it is divided into two streams, one of which is fed to the gasifier with ICFB and the second into the cathode channel. The products of electrochemical reactions leaving the SOFC are feeding to the combustion chamber of the gasifier, where all unreacted components are catalytically burned. After oxidation, the exhaust gases are sent to preheat the incoming air and to dry the coal.

Table 1 shows the composition of the generator gas as a function of temperature in the gasifier [12].

Table 1. The composition of the producer gas as a function of temperature in the gasifier

\begin{tabular}{|c|c|c|c|c|c|c|c|}
\hline $\begin{array}{c}\text { Temperature, } \\
{ }^{\circ} \mathrm{C}\end{array}$ & $\mathrm{CO}_{2}$ & $\mathrm{OO}_{2}$ & $\mathrm{~N}_{2}$ & $\mathrm{CH}_{4}$ & $\mathrm{CO}$ & $\mathrm{H}_{2}$ & $\begin{array}{c}\text { Calorific } \\
\text { value, } \\
\mathrm{MJ} / \mathrm{m} 3\end{array}$ \\
\hline 760 & $10.90 \%$ & $4.80 \%$ & $65.80 \%$ & $0.80 \%$ & $12.20 \%$ & $5.50 \%$ & 2.4 \\
\hline 825 & $7.70 \%$ & $3.10 \%$ & $61.70 \%$ & $1.20 \%$ & $19.50 \%$ & $6.80 \%$ & 3.6 \\
\hline 875 & $7 \%$ & $2.60 \%$ & $60.80 \%$ & $0.90 \%$ & $22.50 \%$ & $6.20 \%$ & 3.8 \\
\hline 900 & $4.50 \%$ & $2.10 \%$ & $59.80 \%$ & $0.40 \%$ & $26 \%$ & $7.20 \%$ & 4.2 \\
\hline
\end{tabular}




\subsection{Calculation of the available electrical power of SOFC stack}

Based on the experimental data obtained, calculations can be made to determine the power of the SOFC stack.

In the solid oxide fuel cell on the anode, the adsorbed and catalytically activated fuel molecule, for example $\mathrm{H}_{2}$ or $\mathrm{CO}$, interacts with the oxygen ion entering the electrolyte from the cathode channel, resulting in the formation of $\mathrm{H}_{2} \mathrm{O}$ or $\mathrm{CO}_{2}$ molecules and free electrons appear [1]

$$
\mathrm{H}_{2}+\mathrm{O}^{2-}=\mathrm{H}_{2} \mathrm{O}+2 \mathrm{e}^{-} ; \quad \mathrm{CO}+\mathrm{O}^{2-}=\mathrm{CO}_{2}+2 \mathrm{e}^{-} .
$$

Since the fuel cells usually operate under isobaric-isothermal conditions, the calculation of the EMF is carried out proceeding from the fact that for these conditions the maximum possible work that can be obtained in the system with a reversible chemical reaction is equal to a decrease in the Gibbs free energy. In this case, in order to calculate the EMF of cell, depending on the partial pressures of the reacting gases and reaction products, it can be used the following equation

$$
E_{\mathrm{e}}=E^{0}-\frac{R \mathrm{~T}}{n_{\mathrm{e}} F} \Sigma \ln p_{k}^{v_{k}}
$$

$E_{\mathrm{e}}^{0}-$ standard EMF element for current-forming reactions [1]; $p_{k}-$ partial pressure components of the mixture; $v_{k}$ - the stoichiometric coefficient of the component in the reaction: positive for the products, negative for the consumables; $\mathrm{T}$ - absolute temperature, $\mathrm{K} ; R=8,314 \mathrm{~J} /(\mathrm{mol} \cdot \mathrm{K}) ; n_{\mathrm{e}}-$ number of electrons participating in a given reaction, for example, $n_{\mathrm{e}}=2$.

\section{Results and Discussion}

Based on reactions kinetics, electrode designs and experimental data, it is determined that the main contribution to the SOFC EMF is made by the hydrogen oxidation reaction, and the CO present in the synthesis gas contributes about 3\% to the EMF cell [1]. In Fig. 3 shows the dependence of the SOFC EMF on the temperature in the gasifier for the case in which the EMF is obtained only from the hydrogen reaction and in the case of $\mathrm{CO}$ participation. It can be seen from the graph that the EMF of a single element decreases with increasing temperature.

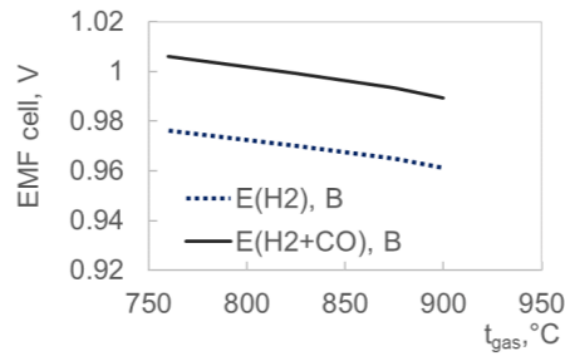

Fig. 3. Dependence of EMF on the temperature at the outlet from the gasifier.

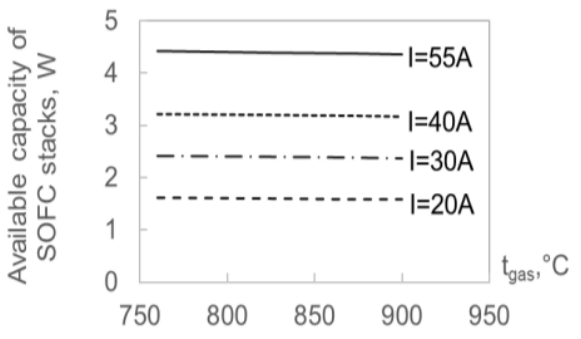

Fig. 4. Dependence the power without loss from the temperature at the outlet of the gasifier

The power received from an electrochemical generator based on SOFC depends on the number of connected cells and stacks, as well as on the current and the losses. Preliminary power estimation was carried out for existing and tested in the UIC, LLC of planar design SOFC stack with a supported nickel anode [20] based on the following parameters: two fuel cells in each of which 40 units each. The parameters of the current are determined from the 
experimental data taking into account the technical characteristics of the equipment. Figure 4 shows the available electrical power (excluding activation, concentration and ohmic losses), which can be obtained from fuel cells considering the concentrations of combustible components in the generator gas. It can be seen from the graph that in the temperature range from 750 to $900^{\circ} \mathrm{C}$ the composition of the generator gas does not introduce any significant changes in the power of SOFC stacks. This makes it possible to regulate the operation of the gasifier in a sufficiently large temperature range.

\section{Conclusions}

- As a result of the analysis of the characteristics of coal gasification and SOFC technologies, several significant aspects have been identified that allow them to be successfully combined in a single thermal scheme with high efficiency and safety.

- Using the gasifier with a fluidized inhibited fluidized bed makes it possible to exclude the generator gas purification module from tar, it increases the efficiency of the energy system and makes it more reliable.

- Using of products from SOFC in the combustion chamber of the gasifier lowers the consumption of coal and supports the endothermic reactions in the gasification zone.

- Analysis dependence EMF from the produced generator gas composition in the range from 750 to $900^{\circ} \mathrm{C}$, showed no significant effect of this parameter on the available power of the electrochemical generator in the specified temperature range, which allows using more control regimes.

\section{References}

1. V. Munts, Y. Volkova, N. Plotnikov, M. Dubinin, V. Tuponogov, V.A. Chernishev, Thermal Engineering, 62(11), 779-784 (2015)

2. H. Kenji. ECS Trans. 57 (1), 3-10 (2013)

3. S. D. Vora. ECS Trans. 57(1), 11-19 (2013)

4. N. Christiansen, S. Primdahl, M. Wandel, S. Ramousse, and A. Hagen. ECS Trans., 57(1), 43-52 (2013)

5. L. Blum, P. Batfalsky, L.G.J. de Haart, J. Malzbender, N. H. Menzler, R. Peters, W. J. Quadakkers, J. Remmel, F. Tietz, and D. Stolten, ECS Trans., 57 (1), 23-33 (2013)

6. Sh. Wang, Z. Zhan, T. Wen. ECS Trans, 57 (1), 35-41 (2013)

7. D. Grasmanis, D. Sovetnikov, D. Baranova, Magazine of Civil Engineering, 8, 140-155 (2017)

8. A. Gorshkov, N. Vatin, P. Rymkevich, O.Kydrevich, Magazine of Civil Engineering, 2, 65-75 (2018).

9. D. Tapobrata, D. Singdeo, A. Pophale, M. Bose, P. Ghosh, Energy Procedia, 54, 748 755 (2014)

10. A. Pernaa, M. Minutillob, E. Jannellib, V. Cigolottic, S.W. Namd, K. Joong, Applied Energy, 227, 80-91 (2018)

11. Z. Din, Z. Zainal, Renewable and Sustainable Energy Reviews, 53, 1356-1376 (2016)

12. A.M. Dubinin, S.P. Mavrin, Solid Fuel Chemistry, 3, 177-183 (2016)

13. J. Karla, T. Pröll, Renewable and Sustainable Energy Reviews, 98, 64-78 (2018) 
14. Z. Chen, L. Gao, X. Zhang, W. Han, S. Li, Energy, 159, 810-816 (2018)

15. P.T. Williams, J. Onwudili. Energy \& Fuels, 20, 1259-1265 (2006)

16. Y. Matsumura, T. Minowa, B. Potic, S.R.A. Kersten, W. Prins, W. van Swaaij, B. Beld, D. Elliott, G. Neuenschwander, A. Kruse, M. Antal. Biomass \&Bioenergy, 29, 269-292 (2005)

17. A. Thattai, V. Oldenbroek, L. Schoenmakers, T. Woudstra, P. Aravind. Applied Thermal Engineering, 114, 170-185 (2017)

18. M. Yari, A. Saberi Mehr, S. Mohammad, S. Mahmoudi, M. Santarelli, Energy, 114, 586-602 (2016)

19. A. Susastriawan, H. Saptoadi, Purnomo, Renewable and Sustainable Energy Reviews, 76, 989-1003 (2017)

20. A. Baskakov, Yu. Volkova, N. Plotnikov, Journal of Engineering Physics and Thermophysics, 87(4), 763-772 (2014)

21. A. Baskakov, N. Plotnikov, Y. Volkova., W. Wang, J. Peng, Z. Dong, X. Lu, Q. Luo ECS Trans,. 68 (1), 327-332 (2015)

22. H. Jeong, M. Geis, C. Lenser, S. Lobe, S. Herrmann, S. Fendt, N. Menzler and O. Guillon, International Journal of Hydrogen Energy, 43(45), 20911-20920 (2018)

23. M. Rios, A.González, E. Lora, O.del Olmo. Biomass and Bioenergy, 108, 345-370 (2018) 